\title{
EFEK TOKSISITAS FRAKSI ETIL ASETAT AKAR SENGGANI (Melastoma affine D.Don ) PADA ORGAN HEPAR, GINJAL DAN TESTIS
}

\author{
TOXICITY EFFECT OF ETHYL ACETATE \\ FRACTION OF Melastoma affine D.Don ROOT ON \\ LIVER, KIDNEY AND TESTIS
}

\author{
Moch.Saiful Bachri \\ Fakultas Farmasi, Universitas Ahmad Dahlan, Yogyakarta \\ e-mail: msaifulbachri@yahoo.co.id
}

\begin{abstract}
Abstrak
Senggani (Melastoma affine D.Don) merupakan tanaman yang banyak ditemukan di wilayah Asia tenggara dan China. Tanaman ini banyak di gunakan sebagai obat tradisional. Penelitian ini bertujuan untuk mengetahui efek toksik senggani terhadap organ-organ vital. Sejumlah 32 ekor tikus jantan jenis Wistar di bagi menjadi 5 kelompok. Kelompok Kontrol $(n=8)$, kelompok Fraksi Etil asetat akar senggani (FEAS) dosis $62.5 \mathrm{mg} / \mathrm{kgBB}(\mathrm{n}=6)$, dosis $125 \mathrm{mg} / \mathrm{kgBB}(\mathrm{n}=6)$, dosis 250 $\mathrm{mg} / \mathrm{kgBB}(\mathrm{n}=6)$, dosis $500 \mathrm{mg} / \mathrm{kgBB}(\mathrm{n}=6)$. Kelompok kontrol disuntik secara per oral dengan bahan pensuspensi FEAS yaitu CMC Na $0.5 \%$. Pemberian fraksi etil asetat akar senggani selama 22 hari. Pada hari ke-23 dilakukan pembedahan dan dilakukan pemeriksaan histopatologik pada organ testis, ginjal dan hepar. Hasil pengamatan pada ginjal dan hepar, pemberian FEAS untuk semua dosis tidak ada perbedaan dibandingkan dengan kelompok kontrol, sementara pada organ testis pemberian FEAS dosis $250 \mathrm{mg} / \mathrm{kgBB}$ dan $500 \mathrm{mg} / \mathrm{kgBB}$ menunjukkan terjadinya nekrosis pada tubulus seminiferus dan terlihat jumlah sperma mengalami penurunan. Kesimpulan penelitian ini, pemberian fraksi etil asetat akar senggani menyebabkan efek toksik pada organ testis ditunjukkan dengan adanya nekrosis pada tubulus seminiferus.
\end{abstract}

Kata Kunci : Fraksi etil asetat, akar senggani, ginjal, hepar, testis 


\section{Abstract}

Melastoma affine (MA) is a medicinal plant commonly found in south East Asia and China. The aim of the study is to investigate the toxicity effect of MA toward vital organs. Thirty two Wistar adult male rats were divided into five groups consisting of six animals each the rats in group except control group, eight animals. The rats in group I (control) were administered $0.5 \%$ CMC Na orally, while CMC Na suspension of ethyl acetate fraction of MA root $(62.5,125,250$, and $500 \mathrm{mg} / \mathrm{kg}$ body weight) were given to the II, III, IV and V groups, respectively. The CMC Na suspensions of ethyl acetate fraction of MA root were administered for 22 days. Rats were sacrificed at the $23^{\text {th }}$ day. Liver, kidney, testis were collected for histopathological observation. The observation result on liver and kidney showed no difference compare to control groups, meanwhile on testis, the administration of ethyl acetate fraction of MA root at dose $(250,500 \mathrm{mg} / \mathrm{kg}$ body weight) caused necrosis on seminiferus tubules and decreasing sperm counting. The conclusion, administration of ethyl acetate fraction of MA root caused toxicity effect on testis with necrosis on seminiferus tubules.

Key words : melastoma affine root, ethyl acetate fraction, liver, kidney, testis

\section{PENDAHULUAN}

Upaya mencari bahan obat atau kontrasepsi pria dengan syarat: efektif, aman, terbalikkan, mudah digunakan, cepat kerjanya, tanpa berakibat buruk terhadap potensi seks dan libido (Griffin, 1995) dengan memanfaatkan bahan dari tanaman dan hewan telah banyak dilakukan, seperti cacing Lumbricus rubellus (Murwiningsih, 2001), biji papaya mempunyai daya menurunkan fertilitas tikus jantan (Sarifuddin dkk, 1986), terong tukak, buah pare mampu menghambat spermatogenesis tikus putih (Alfera, 1994; Ghufron dan Herwiyati, 1995), biji saga menghambat spermatogenesis tikus (Djannah, 1996).
Senggani (Melastoma affine D.Don) merupakan tanaman yang

banyak ditemukan di wilayah Asia tenggara dan China. Tanaman ini banyak di gunakan sebagai obat tradisional seperti dispepsia, disentri, diare, hepatitis, radang dinding pembuluh darah, pembekuan darah (Anonim, 2002). Ekstrak etanol akar senggani berpengaruh pada proses spermatogenesis (Irwan, 2001). Menurut Bachri (2004) fraksi etil asetat dan fraksi tidak larut etil asetat akar senggani menyebabkan penurunan motilitas dan jumlah sperma.

Melihat potensi senggani yang dapat di gunakan sebagai antispermatogenesis, penting sekali untuk melihat efek toksik dari senggani terhadap organ-organ vital. 


\section{BAHAN DAN METODE}

Hewan

Tikus jenis Wistar (berat $200 \square \pm 10$ g) umur 12 minggu diperoleh dari laboratorium Farmakologi dan Toksikologi UGM. Semua hewan dilakukan perawatan di laboratorium Farmakologi dan Toksikologi UGM dan dilaksanakan sesuai standar dari Jurusan Farmakologi dan Toksikologi Fakultas farmasi UGM. Tikus diadaptasikan selama 1 minggu dengan mendapatkan pakan dan minum secukupnya.

\section{Fraksinasi}

Akar Senggani yang diperoleh dari balai Penelitian Tanaman Obat (BPTO) Tawangmangu Karanganyar Jawa tengah dilakukan pengeringan, dipotong tipis-tipis dan diserbuk. Serbuk dimaserasi dengan etanol sampai $3 \mathrm{x}$ selama 3 hari, disaring dan di uapkan untuk mendapatkan ekstrak etanol. Ekstrak etanol kemudian difraksinasi menggunakan etil asetat untuk mendapatkan fraksi etil asetat akar senggani (FEAS). FEAS dikeringkan selama 3 hari untuk mendapatkan FEAS kering dan disimpan pada suhu $4^{\circ} \mathrm{C}$ sebelum digunakan.

\section{JALAN PENELITIAN}

FEAS di timbang dan dicampur dengan $\mathrm{CMC} \quad \mathrm{Na} \quad 0.5 \quad \%$ sebagai suspending agent kemudian di homogenkan dengan stirrer. Tikus di bagi ke dalam 5 kelompok. Kelompok Kontrol di beri CMC Na $0.5 \%(n=8)$, FEAS dosis $62.5 \mathrm{mg} / \mathrm{kgBB}$ (FEAS-62.5) $(\mathrm{n}=6), 125 \mathrm{mg} / \mathrm{kgBB}$ (FEAS-125) $(\mathrm{n}=6)$, $250 \mathrm{mg} / \mathrm{kgBB}($ FEAS-250) $(\mathrm{n}=6), 500$ $\mathrm{mg} / \mathrm{kgBB} \quad($ FEAS-500) $\quad(\mathrm{n}=6)$. Semua pemberian secara oral selama 22 hari. Pada hari ke-23 di lakukan pengamatan dengan cara tikus dibedah, sebelumnya dianestesi menggunakan dietil eter. Organ hepar, ginjal dan testis diambil untuk pemeriksaan histopatologik.

Pemeriksaan Histopatologik

Untuk pemeriksaan, organ-organ dimasukkan ke dalam larutan formalin 10\% selama 2 hari, kemudian dipotong melintang dan diproses untuk dibuat preparat histologi sesuai standar yang dilakukan di Bagian Patologi Fakultas Kedokteran hewan UGM dengan pengecatan Hematoksilin-Eosin

\section{HASIL DAN PEMBAHASAN}

\section{Pemeriksaan Histologi}

Pemeriksaan histologi diperlukan untuk mengetahui kerusakan-kerusakan pada organ target yang dapat dipakai sebagai prediksi kemungkinan mekanisme aktivitas farmakologi maupun toksikologi.

\section{Ginjal dan Hepar}

Hasil pemeriksaan ginjal dan hepar menunjukkan pemberian FEAS semua dosis tidak berpengaruh (tidak ada perubahan) pada gambaran histologinya jika dibandingkan dengan kelompok kontrol (normal) (gambar tidak ditampilkan).

\section{Testis}

Pada Gambar 1 memperlihatkan gambaran mikroskopik kelompok kontrol menunjukkan morfologi sel-sel testis yang normal. Lumen-lumen 
tubulus seminiferus testis penuh dengan sel-sel spermatogonia, spermatid, spermatozoa, dan sel-sel sertoli

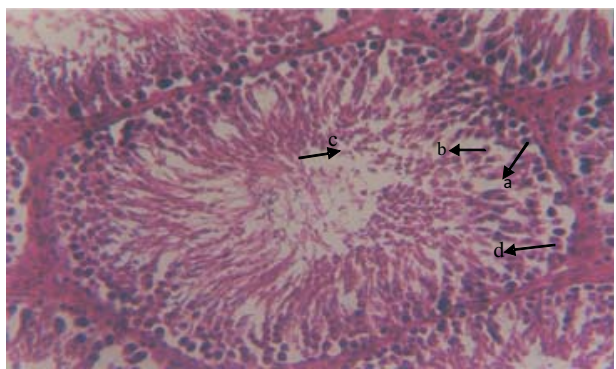

Gambar 1. Gambaran mikroskopik tubulus seminiferus testis kelompok kontrol a. spermatogonia, b. spermatid, c. spermatozoa, d.sel sertoli

Pada Gambar 2 memperlihatkan hasil pemeriksaan histologi testis tikus yang diberi perlakuan FEAS-500, terjadi perubahan morfologi sel-sel testis, adanya nekrosis pada sel-sel pembentuk spermatozoa ditandai dengan berkurangnya spermatogonium, spermatid, dan spermatozoa. Lumen-lumen tubulus seminiferus kosong dengan spermatozoa. Hal ini menunjukkan adanya gangguan pada proses spermatozoa.

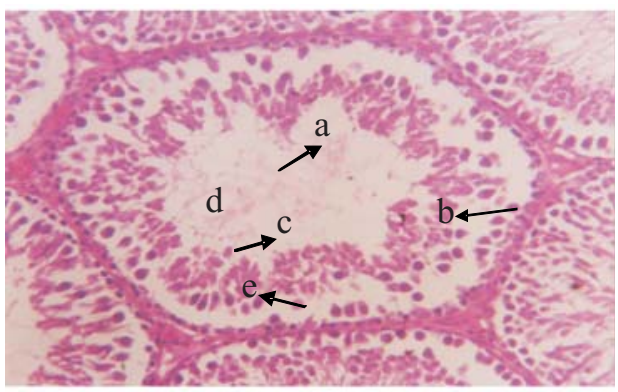

Gambar 2. Gambaran mikroskopik tubulus seminiferus testis kelompok FEAS-500. a.

Lumen kosong berkurangnya spermatozoa b.spermatogonia c.spermatid d.spermatozoa e.sel sertoli

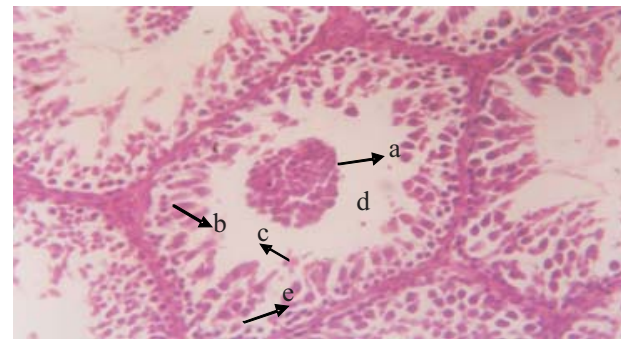

Gambar 3. Gambaran mikroskopik tubulus seminiferus testis kelompok FEAS-250. a. Nekrosis sel-sel pembentuk spermatozoa b. spermatogonia c spermatid d.spermatozoa e.sel sertoli

Pemberian FEAS-250 menyebabkan terjadinya perubahan morfologi tubulus seminiferus testis (Gambar 3). Kerusakan lebih parah dibandingkan dengan FEAS-500, spermatogonia, spermatid, spermatozoa jumlahnya sangat sedikit. Hal ini disebabkan karena terjadinya nekrosis pada sel-sel pembentuk spermatozoa.

Pemberian FEAS-125 dan FEAS62.5 tidak menyebabkan terjadinya perubahan morfologi tubulus seminiferus testis. Gambaran histologinya sama dengan kelompok kontrol (gambar tidak ditampilkan).

Dari hasil histopatologi pada organ testis, FEAS-500 dan FEAS-250 mempunyai efek toksik pada organ testis, menyebabkan terjadinya perubahan lumen tubulus seminiferus, ditandai dengan adanya nekrosis sehingga berakibat kosongnya spermatozoa pada lumen tubulus seminiferus. Sementara pada pemberian FEAS-125 dan FEAS-62.5 tidak menyebabkan perubahan pada gambaran morfologi tubulus seminiferus testis tikus. 
Efek toksik FEAS pada testis ini bisa bermakna positif untuk pengembangan obat kontrasepsi pria jika sifatnya reversible, artinya morfologi testis akan kembali normal jika pemberian FEAS dihentikan. Penelitian ini didukung dengan hasil penelitian sebelumnya Bachri (2004) bahwa fraksi etil asetat akar senggani menyebabkan penurunan motilitas dan jumlah sperma.

Kesimpulan bahwa fraksi etil asetat akar senggani menyebabkan efek toksik pada organ testis, tidak menyebabkan efek toksik pada organ liver dan ginjal serta berpotensi dikembangkan sebagai obat kontrasepsi pria.

\section{DAFTAR PUSTAKA}

Alfera, D. 1994, Gambaran Histologik spermatogenesis tikus putih (Rattus novergicus) setelah diberi makan juice buah Pare (Mamordica Chatarantia L), KTI, FKU UGM, Yogyakarta.

Anonim, 2002 ,

http://www.iptek.net.id/ind/cakra obat/tanamanobat.

Bachri,M.S,2004, Pengaruh Pemberian Fraksi etil asetat dan fraksi tidak larut etil asetat akar senggani (Melastoma affine D.Don) terhadap spermatogenesis tikus putih, Tesis, Universitas Gadjah Mada, Yogyakarta.
Djannah, S.N., 1996, Pengaruh Pemberian Ekstrak Biji Saga (Abrus precatorius Linn) Pada Spermatogenesis dan Gambaran Kromosom Tikus Jantan Fertil (Rattus rattus var wistar), Tesis, Universitas Airlangga, Surabaya.

Ghufron, M., dan Herwiyanti, S., 1995, Gambaran Histologik Spermatogenesis Tikus Putih (Rattus Novergicus) Setelah diberi Terung Tukak (Solanum forvum), J. Ked Yarsi, 28-35.

Griffin, P.D., 1995, Methods for the Regulation of Male Fertility, Annual Report WHO, 75-81.

Irwan, Y.D., 2001, Pengaruh Pemberian Ekstrak Etanol Akar Senggani (Melastoma polyanthum Bl) Terhadap Spermatogenesis Tikus Putih, Skripsi, Universitas Sanata Dharma, Yogyakarta.

Murwiningsih, 2001, Pengaruh Pemberian Suspensi Cacing Lumbricus rubellus Terhadap Spermatogenesis Tikus Putih jantan (Rattus Novergicus), Skripsi, Universitas Ahmad Dahlan, Yogyakarta.

Sarifuddin, Salmiati, Zulkarnain S., 1986. Pengaruh Biji Pepaya ( Carica Papaya Linn) Terhadap Spermatogenesis Mencit, Prosiding PANDI, 209-233, Yogyakarta. 